Vietnam Journal of Mechanics, VAST, Vol.32, No. 3 (2010), pp. $157-166$

\title{
2D - MODEL OF CONTAMINANT WATER TRANSMISSION PROCESSES AND NUMERICAL SIMULATION ON A NATURAL LAKE
}

\author{
Tran Thu Ha, Nguyen Hong Phong \\ Institute of Mechanics
}

\begin{abstract}
Nowadays, the water pollution problems in the lakes are urgent matters. The simulation of contaminant water transmission process plays important role in reality to improve people's life qualities. In this paper the 2D- mathematical model simulating transmission processes of some contaminant substances in one lake of Hanoi is studied. The finite volume method is used in model. The actions between substances are considered and the simulation results are compared with the measurements.
\end{abstract}

\section{INTRODUCTION}

Present-day in our country, water pollution is one of the most serious problems. Water quality is influenced directly to health of people. In this paper the $2 \mathrm{D}$ hydraulic and pollution models are used to simulate the transmissions of the pollution substances. The linear $2 \mathrm{D}$ water pollution model is studied by semi group method in [5]. The nonlinear 2D-Imech water pollution model is begun establishing in 2005 [1] by the group of Assoc. Prof. Hoang Van Lai. In this paper this model is developed to simulate transmission of the pollution substance combination acting each with others in water.

\section{FORMULATION OF THE WATER POLLUTION PROBLEM}

2D Pollution water model is consisted of hydraulic model and transmission - diffusion of pollution substances. The Saint - Vernant equation is written as follows:

$$
\begin{gathered}
\left.\frac{\partial z}{\partial t}+\frac{\partial}{\partial x}(u h)+\frac{\partial}{\partial y}(v h)=0 \quad \text { (in } \Omega\right) \\
\left.\frac{\partial u}{\partial t}+u \frac{\partial u}{\partial x}+v \frac{\partial u}{\partial y}+g \frac{\partial z}{\partial x}=-\frac{g u\left(u^{2}+v^{2}\right)^{1 / 2}}{K_{x}^{2} h^{4 / 3}} \quad \text { (in } \Omega\right) \\
\left.\frac{\partial v}{\partial t}+u \frac{\partial v}{\partial x}+v \frac{\partial v}{\partial y}+g \frac{\partial z}{\partial y}=-\frac{g v\left(u^{2}+v^{2}\right)^{1 / 2}}{K_{y}^{2} h^{4 / 3}} \quad \text { (in } \Omega\right)
\end{gathered}
$$

We suppose that there are $m$ substances dissolved in water. Then the transmission and diffusion processes of pollution substances are described by the following equation:

$$
\frac{\partial C_{i}}{\partial t}+\frac{\partial}{\partial x} u C_{i}+\frac{\partial}{\partial y} v C_{i}=f_{i}+D_{i}\left(\frac{\partial^{2}}{\partial x^{2}} C_{i}+\frac{\partial^{2}}{\partial y^{2}} C_{i}\right) \quad(\text { in } \Omega), \quad(i=1 \ldots m)
$$


Here:

$\Omega$-is a bounded domain of $R^{2}$ with a boundary $\Gamma$

$z$ - Free surface elevation,

$h$ - Water height

$u$ - Average velocity by $\mathrm{x}$ direction

$v$ - Average velocity by y direction

$g-$ Gravity acceleration

$K_{x}-$ Strickler coefficient by x direction

$K_{y}$ - Strickler coefficient by y direction

$S_{o, x}-$ Bottom slope by x direction

$S_{o, y}-$ Bottom slope by y direction

$C_{i}$ - Concentration of i-substance

$f_{i}-$ Pollution source of i-substance

$D_{i}$ - the diffusion coefficient of i-substance

$m$ - The number of substances in water

$U=(u, v)-$ water velocity vector

are:

The boundary and initial conditions of Saint - Vernant and water pollution equations

$\left.U(x, y) \cdot \vec{n}\right|_{\Gamma}=\bar{U}(t)$, where $\vec{n}$ is the normal out orthogonal vector onto the perimeter of the region $\Omega$,

$$
\begin{aligned}
& U(x, y, 0)=U_{o}(x, y), \quad z(x, y, 0)=z_{o}(x, y),\left.\quad z\right|_{\Gamma}=\bar{z}(t), \quad C_{i}(x, y, 0)=C_{i, 0}(x, y), \\
& \left.C_{i}(x, y, t)\right|_{(x, y) \in \Gamma_{1}}=\bar{C}_{i}(t) \text { and }\left.\frac{\partial C_{i}}{\partial n}\right|_{\Gamma_{2}}=0, \Gamma=\Gamma_{1} \cup \Gamma_{2} .
\end{aligned}
$$

\section{MATHEMATICAL ALGORITHM CALCULATED 2D WATER POLLUTION}

\subsection{Algorithm of $2 \mathrm{D}$ flow system.}

In this model the finite volume method is used with the calculated triangular mesh. In the regions with complicated topography the flows are well simulated by this grid board. In finite volume method the calculated area is divided by the small simple elements as triangles. The triangular mesh is unstructured and represented as in Fig. 1. The mesh's unstructured properties are represented that the numbering of grids and elements are considered by any rule.

To apply the finite volume the equations (1) - (3) are rewritten as follows:

$$
\frac{\partial V}{\partial t}+\frac{\partial A}{\partial x}+\frac{\partial B}{\partial y}=F
$$

In the equation (5)

$$
V=\left(\begin{array}{c}
z \\
q_{x} \\
q_{y}
\end{array}\right), \quad A=\left(\begin{array}{c}
q_{x} \\
\frac{1}{2} u^{2}+g z \\
u v
\end{array}\right), \quad B=\left(\begin{array}{c}
q_{x} \\
u v \\
\frac{1}{2} v^{2}+g z
\end{array}\right), \quad F=\left(\begin{array}{c}
0 \\
-g u \frac{\sqrt{u^{2}+v^{2}}}{K_{y}^{2} h^{4 / 3}}+u \frac{\partial v}{\partial y} \\
-g v \frac{\sqrt{u^{2}+v^{2}}}{K_{y}^{2} h^{4 / 3}}+v \frac{\partial u}{\partial x}
\end{array}\right)
$$




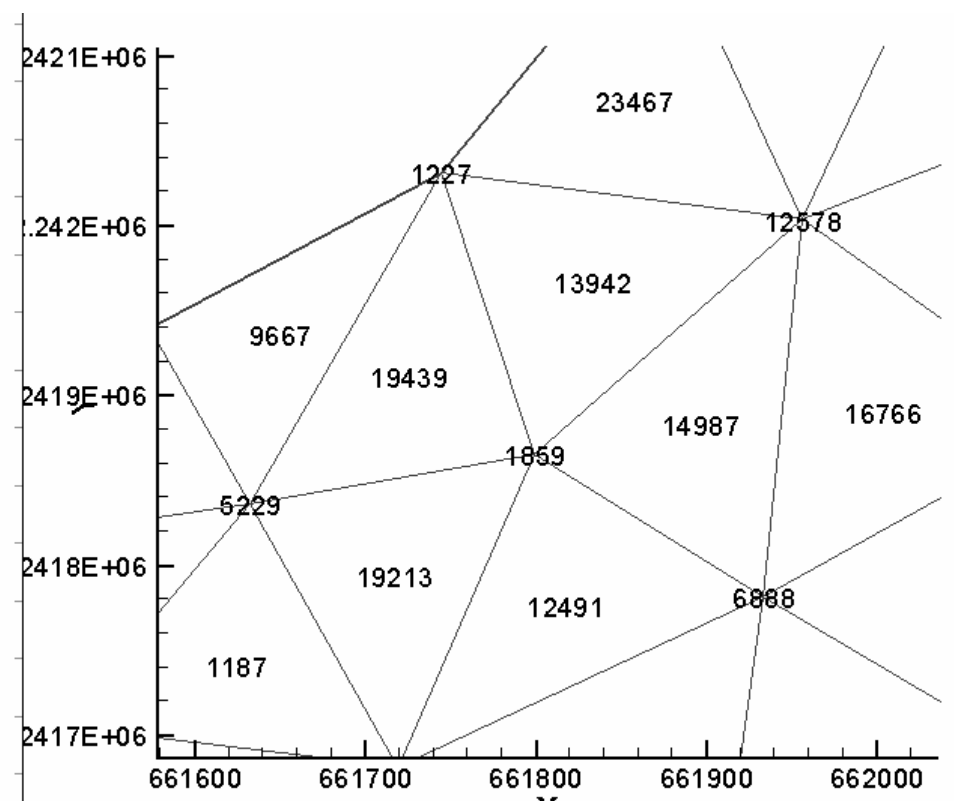

Fig. 1. The unstructured mesh

Integrating two sides of equation system (5) by small element $\mathrm{S}$ we have the formula:

$$
\int_{S} \frac{\partial V}{\partial t} d S+\int_{S} \nabla \cdot(A, B) d S=\int_{S} F d S
$$

To approximate these integrals we assume that in small element $S$ the functions $z, u, v$ can be the constants. Therefore, using Green formula the above formula can be rewritten as following:

$$
\frac{d V}{d t} S_{+} \oint_{\partial S}(A, B) \cdot \vec{n} d(\partial S)=\int_{S} F d S
$$

In (6), $S$ is the area of element, $\partial S$ is the perimeter of element, $\mathrm{n}$ is the out normal orthogonal vector onto $\partial S$. In the slow changing process problem to calculate the integrals we can use the average values for the functions in $S$ element.

\subsection{Mathematical algorithm for transmission-diffusion equations}

The transmission pollution substance equation (4) can be rewritten as follows:

$$
\frac{\partial C_{i}}{\partial t}+u \frac{\partial C_{i}}{\partial x}+v \frac{\partial C_{i}}{\partial y}-\frac{\partial}{\partial x}\left(D_{i} \frac{\partial C_{i}}{\partial x}\right)-\frac{\partial}{\partial y}\left(D_{i} \frac{\partial C_{i}}{\partial y}\right)=f_{i}
$$

Or

here $U=(u, v)$.

$$
\frac{\partial C_{i}}{\partial t}+U \operatorname{grad} C_{i}-\nabla \cdot D_{i} g r a d C_{i}=f_{i}
$$


The pollution process model is depending on the combination of substances and number of them. The following substances and the conversion terms are considered:

Table 1. The substances and conversion terms

\begin{tabular}{|c|c|}
\hline Variable & Conversion term \\
\hline SS & Er - De \\
\hline BOD & Hyd + FastCoxid $-\mathrm{R}_{\mathrm{ON}}$ Denitri 2 Denitri + Sed $_{\mathrm{BOD}}-$ Sett $_{\mathrm{BOD}}$ \\
\hline CHL & Growth $_{\mathrm{CHL}}-$ Death $_{\mathrm{CHL}}-$ Resp $_{\mathrm{CHL}}-$ Settl $_{\mathrm{CHL}}$ \\
\hline DO & 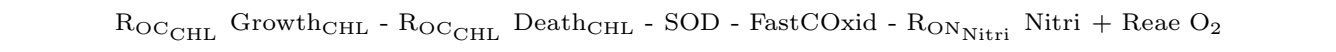 \\
\hline $\mathrm{NH}_{4}$ & $\mathrm{R}_{\mathrm{NO}_{\mathrm{Hyd}}} \mathrm{Hyd}-\mathrm{R}_{\mathrm{NC}_{\mathrm{CHL}}} \mathrm{P}_{\mathrm{ap}}$ Growth $\mathrm{CHL}-\mathrm{R}_{\mathrm{NC}_{\mathrm{CHL}}}$ Re spCHL $-\mathrm{Nitri}+\operatorname{Sed}_{\mathrm{NH}_{4}}$ \\
\hline $\mathrm{NO}_{3}$ & Nitri - Denitri - $\mathrm{R}_{\mathrm{NO}_{3}{ } \mathrm{C}_{\mathrm{CHL}}}\left(1-\mathrm{P}_{\mathrm{ap}}\right)$ Growth $\mathrm{CHL}-\operatorname{Sed}_{\mathrm{NO}_{3}}$ \\
\hline $\mathrm{C}_{\mathrm{T}}$ & $\mathrm{R}_{\mathrm{CC}_{\text {FastCOxid }}}$ FastCOxid $+\mathrm{R}_{\mathrm{CC}_{\text {Re sp }}}$ Re spCHL $-\mathrm{R}_{\mathrm{CC}_{\text {Growth }}}$ Growth $\mathrm{CHL}_{1}+\mathrm{Reae}_{\mathrm{CO}_{2}}+\mathrm{Sed}_{\mathrm{CO}_{2}}-\mathrm{Prep}_{\mathrm{CO}_{3}}$ \\
\hline ALK & $\mathrm{R}_{\mathrm{ALK}, \mathrm{CHL}} \operatorname{Resp}_{\mathrm{CHL}}-\left(\mathrm{R}_{\mathrm{ALK}}, \mathrm{CHL} \mathrm{P}_{\mathrm{ap}}-\mathrm{R}_{\mathrm{ALK}, \mathrm{N}}\left(1-\mathrm{P}_{\mathrm{ap}}\right)\right)$ Growth $_{\mathrm{CHL}}-\mathrm{R}_{\mathrm{ALK}}$, Nitri Nitri $+\mathrm{R}_{\mathrm{ALK}}$, Denitri Denitri \\
\hline $\mathrm{pH} /\left[\mathrm{H}_{+}\right]$ & $\mathrm{f}\left(\left[\mathrm{H}_{+}\right]\right)$ \\
\hline
\end{tabular}

In the right side of equation (7) the combination of substances are considered and represented by the source functions $f_{i}(i=1, \ldots, m)$. These functions $f_{i}$ are called by conversion terms and written as follows: $f_{i}=\sum_{j=1}^{m} k_{i, j} C_{j}(i, j=1, m)$. Here, $m$ is the number of pollution substances and $k_{i, j}(i, j=1, . ., m)$ are the coefficients depending on temperatures and different substances.

Integrating two sides of equation (7) by $\mathrm{dx}$ and dy we have:

$$
\int_{S} \frac{\partial C_{i}}{\partial t} d x d y+\int_{S}\left(\operatorname{div}\left(U C_{i}\right)-C_{i} d i v U\right) d x d y-\int_{S} \nabla\left(D_{i} \operatorname{grad} C_{i}\right) d x d y=\int_{S} \sum_{j=1}^{m} k_{i, j} C_{j} d x d y
$$

Using the Green formula for the above equation we have:

$$
\int_{S} \frac{\partial C_{i}}{\partial t} d x d y+\int_{\partial S} U C_{i} \vec{n} \partial S-\int_{S} C_{i} d i v U d x d y-\oint_{\partial S} D_{i} \operatorname{grad} C_{i} . \vec{n} \partial S=\int_{S} \sum_{j=1}^{m} k_{i, j} C_{j} d x d y
$$

Then the equation can be discrete by the following equation:

$$
\frac{C_{i}-C_{i, t}}{\Delta t} d S+\left(u C_{i, t}-D_{i} \frac{\partial C_{i, t}}{\partial x}\right) n_{x} . \partial S+\left(v C_{i, t}-D_{i} \frac{\partial C_{i, t}}{\partial y}\right) n_{y} . \partial S-C_{i, t} \frac{z_{i}-z_{i, t}}{h \Delta t} d S=\sum_{j=1}^{n} k_{i, j} C_{j, t} d S
$$


Here the functions are calculated at the center point of element; dS is the area of element; $\partial S$ is the perimeter of element; $C_{t}$ is the concentration in the last step; $\vec{n}=$ $\left(n_{x}, n_{y}\right)$ out normal orthogonal vector of element; $u, v$ and $z$ are the values solving from $(6) ; z_{t}$ is the value of $\mathrm{z}$ in the previous step. Then the concentration of substance $C_{i}$ can be calculated by the following formula:

$$
\begin{gathered}
C_{i}=\left(k_{i, 1} C_{i, t}+k_{i, 2} C_{2, t}+\ldots+k_{i, n} C_{n, t}\right) \Delta t+C_{i, t}\left(\frac{z_{-} z_{t}}{h}+1\right)- \\
-\left(u C_{i, t}-D_{i} \frac{\partial C_{i, t}}{\partial x}\right) \frac{n_{x} \partial S \Delta t}{d S}-\left(v C_{i, t}-D_{i} \frac{\partial C_{i, t}}{\partial y}\right) \frac{n_{y} \partial S \Delta t}{d S}
\end{gathered}
$$

\section{EXPERIMENTAL SIMULATION FOR THANH NHAN LAKE}

Thanh Nhan lake is located behind Thanh Nhan hospital. Its area, water height, water capacity respectively are $8.1 \mathrm{ha}, 1.5 \mathrm{~m}-3 \mathrm{~m}$ and $162.0000 \mathrm{~m}^{3}$. Waste water flowing into lake is about $2100 \mathrm{~m}^{3}$ per day-night.

\section{a. Physical hydro properties}

- Temperature of lake is oscillated from $23.4^{\circ} \mathrm{C}$ to $23.8^{\circ} \mathrm{C}$ in dry season.

- $\mathrm{pH}$ level is oscillated from $7.88 \mathrm{mg} / \mathrm{l}$ to $8.57 \mathrm{mg} / \mathrm{l}$

- Muddy level is oscillated from $9 \mathrm{mg} / \mathrm{l}$ to $34 \mathrm{mg} / \mathrm{l}$.

- Salt level (NaCL) isn't changed in at the stations getting samples $0.01 \%$

- Oxygen concentration dissolved in water is oscillated from $7.9 \mathrm{mg} / \mathrm{l}$ to $11.6 \mathrm{mg} / \mathrm{l}$.

b. Chemical hydro properties:

* Organic element group:

- The contents of elements that have the origin Nitrogen such as $\mathrm{NO}_{2}, \mathrm{NO}_{3}$, and $\mathrm{NH}_{3}$ having the following development processes:

+ The content of $\mathrm{NO}_{2}$ is oscillated from $0,055 \mathrm{mg}$ to $0.062 \mathrm{mg} / 1$ higher than permitted critical value of surface water standard in Vietnam $(0.01-0.05 \mathrm{mg} / \mathrm{l})$

+ The content of $\mathrm{NO}_{3}$ is oscillated from $0.76 \mathrm{mg}$ to $0.81 \mathrm{mg} / \mathrm{l}$ lower very much than permitted critical value of surface water standard in Vietnam $(10-15 \mathrm{mg} / \mathrm{l})$.

+ The content of $\mathrm{NH}_{3}$ is oscillated from $0.51 \mathrm{mg}$ to $0.62 \mathrm{mg} / \mathrm{l}$ not higher than permitted critical value of surface water standard in Vietnam $(1 \mathrm{mg} / \mathrm{l})$.

+ The content of $\mathrm{PO}_{4}$ dissolved in water is oscillated from $0.44 \mathrm{mg} / 1$ to $0.46 \mathrm{mg} / \mathrm{l}$

+ The content of salt that has origin $\mathrm{SO}_{4}$ is oscillated from $25 \mathrm{mg} / 1$ to $27 \mathrm{mg} / \mathrm{l}$.

+ The content of substances that have origin $\mathrm{H}_{2} \mathrm{~S}$ is oscillated from $0.116 \mathrm{mg} / \mathrm{l}$ to $0.151 \mathrm{mg} / \mathrm{l}$.

+ The need of chemical biology oxygen $\mathrm{BOD}_{5}$ is oscillated from $15.5 \mathrm{mg} / 1$ to 24.0 $\mathrm{mg} / \mathrm{l}$ less than Vietnamese critical standard of surface water quality (less than $25 \mathrm{mg} / \mathrm{l}$ ).

+ The need of chemical oxygen COD is oscillated from $345 \mathrm{mg} / \mathrm{l}$ to $400 \mathrm{mg} / \mathrm{l}$. Therefore, the chemical oxygen need is higher than Vietnamese critical standard of surface water quality about 10 times (less than $35 \mathrm{mg} / \mathrm{l}$ ).

* The group of chemical toxin is consisted of some elements that have heavy metals such as catmint, mercury, leaden and mange. In general, the average contents of elements, that have heavy metals, are less than Vietnamese critical standard of surface water quality (1995). 
Table 2. Water quality of Thanh Nhan lake in $11 / 2001$

\begin{tabular}{|c|c|c|c|c|c|}
\hline & $\begin{array}{l}\text { P1 Gate into } \\
\text { the north of lake }\end{array}$ & $\begin{array}{l}\text { P2 Area in the } \\
\text { middle of lake }\end{array}$ & $\begin{array}{l}\text { P3 Gate } \\
\text { out }\end{array}$ & $\begin{array}{l}\text { Vietnamese critical } \\
\text { standards }\end{array}$ & Remarks \\
\hline Temperature ${ }^{\circ} \mathrm{C}$ & 23.4 & 23.8 & 23.8 & & \\
\hline $\begin{array}{l}\text { Oxygen concentration } \\
\text { dissolved }(\mathrm{mg} / \mathrm{l})\end{array}$ & 7.9 & 10.9 & 11.6 & $\begin{array}{l}\geq 6 \\
\geq 2\end{array}$ & \\
\hline $\mathrm{PH}$ & 7.88 & 8.48 & 8.57 & $\begin{array}{c}6-8 \\
5.5-9\end{array}$ & \\
\hline Derivative level $(\mathrm{S} / \mathrm{m})$ & 0.04 & 0.04 & 0.04 & & \\
\hline $\mathrm{NaCL}(\%)$ & 0.01 & 0.01 & 0.01 & & \\
\hline Muddy level (mg/l) & 9 & 25 & 34 & & \\
\hline $\mathrm{NO}_{2}-\mathrm{N}(\mathrm{mg} / \mathrm{l})$ & 0.055 & 0.057 & 0.062 & $\begin{array}{l}0.01 \\
0.05\end{array}$ & $\begin{array}{l}\text { Over the critical } \\
\text { standards }\end{array}$ \\
\hline $\mathrm{NO}_{3}-\mathrm{N}(\mathrm{mg} / \mathrm{l})$ & 0.81 & 0.78 & 0.76 & $\begin{array}{l}10 \\
15\end{array}$ & \\
\hline $\mathrm{NH}_{3}(\mathrm{mg} / \mathrm{l})$ & 0.52 & 0.51 & 0.62 & $\begin{array}{c}0.05 \\
1\end{array}$ & \\
\hline $\mathrm{SO} 4(\mathrm{mg} / \mathrm{l})$ & 27 & 25 & 25 & & \\
\hline $\mathrm{PO} 4(\mathrm{mg} / \mathrm{l})$ & 0,44 & 0,46 & 0,46 & & \\
\hline $\operatorname{COD}(\mathrm{mg} / \mathrm{l})$ & 400 & 380 & 345 & $\begin{array}{l}<10 \\
<35\end{array}$ & $\begin{array}{c}\text { Over the critical } \\
\text { standard about } 10 \\
\text { times }\end{array}$ \\
\hline $\mathrm{BOD}_{5} 20^{\circ} \mathrm{C}(\mathrm{mg} / \mathrm{l})$ & 24.0 & 15.5 & 17.0 & $\begin{array}{l}<4 \\
<25\end{array}$ & \\
\hline Total Coli form(MPN/100ml) & 280 & & & 5000 & \\
\hline Fecalcoliform(MPN/100ml) & 200 & & & 5000 & \\
\hline $\mathrm{Cu}(\mathrm{mg} / \mathrm{l})$ & 0,00 & 0,00 & 0,00 & $\begin{array}{c}0.1 \\
1\end{array}$ & \\
\hline $\operatorname{Mn}(\mathrm{mg} / \mathrm{l})$ & 0.001 & 0,003 & 0,005 & $\begin{array}{l}0.1 \mathrm{mg} / \mathrm{l} \\
0.8 \mathrm{mg} / \mathrm{l}\end{array}$ & \\
\hline $\mathrm{Pb}(\mu \mathrm{g} / \mathrm{l})$ & 2,740 & 2,370 & 3,140 & $\begin{array}{c}0.05 \mathrm{mg} / \mathrm{l} \\
0.1 \mathrm{mg} / \mathrm{l}\end{array}$ & \\
\hline $\mathrm{Cd}(\mu \mathrm{g} / \mathrm{l})$ & 0,228 & 0,316 & 0,325 & $\begin{array}{l}0.01 \mathrm{mg} / 1 \\
0.02 \mathrm{mg} / \mathrm{l}\end{array}$ & \\
\hline $\mathrm{Hg}(\mu \mathrm{g} / \mathrm{l})$ & 0,089 & 0,076 & 0,091 & $\begin{array}{c}0.001 \mathrm{mg} / \mathrm{l} \\
0.02 / 1\end{array}$ & \\
\hline
\end{tabular}




\section{c. Geographical data}

The geographical data of Thanh Nhan Lake are collected on the map 1:5.000 with the correction corresponding to real condition.

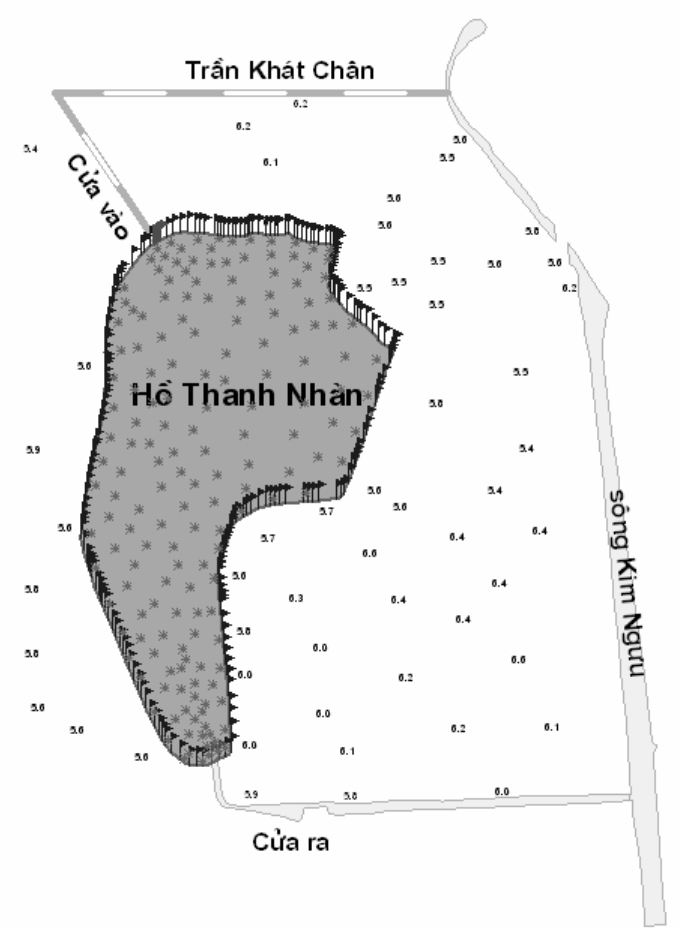

Fig. 2. Geographical map of Thanh Nhan lake

We only use norms of substances in the model such as $\mathrm{BOD}_{5}, \mathrm{SO}_{4}$, and COD. BOD's indicator shows the oxygen quantity needing for bacterium in oxygen reactions of organic substances in water. COD's indicator shows the chemical oxygen's quantity needing for oxygen reactions of organic substances in disintegration processes into $\mathrm{CO}_{2}$ and $\mathrm{H}_{2} \mathrm{O}$. High contents of $\mathrm{SO}_{4}$ influence to the processes introducing $\mathrm{H}_{2} \mathrm{~S}$ in water that makes bad smell and poison to fishes.

The substances $\mathrm{BOD}_{5}, \mathrm{SO}_{4}, \mathrm{COD}$ have exchanging relation. The chemical process disintegrated pollution substances are described as follows:

$\mathrm{S}_{\mathrm{i}}\left(\mathrm{BOD}_{5}\right)=-\mathrm{k}_{1} \cdot \mathrm{BOD}_{5} ; \mathrm{S}_{\mathrm{i}}\left(\mathrm{SO}_{4}\right)=-\mathrm{k}_{7} \mathrm{SO} 4 \mathrm{~S}_{\mathrm{i}}(\mathrm{COD})=\mathrm{k}_{6} \mathrm{COD}$.

On the collected data, we establish the input data for the model. The geographical data are divided into the boundary and inside area of lake. These data are divided by the unstructured net with 1964 triangular elements and 1058 nodes. This geographical map and unstructured net are described as the following Fig. 3 and Fig. 4.

The data of discharges, water height and substance contents in the gate into the lake are as following:

The discharges in and out of lake are $2100 \mathrm{~m}^{3}$ per day-night.

The average water height is $4 \mathrm{~m}$. 

$\mathrm{mg} / \mathrm{l}$.

The content of $\mathrm{BOD}_{5}$ in the gate into lake is equal to the measurement value 24

The content of $\mathrm{SO}_{4}$ in the gate into lake is equal to the measurement value $27 \mathrm{mg} / \mathrm{l}$.

The content of COD in the gate into lake is equal to the measurement value 400 $\mathrm{mg} / \mathrm{l}$.

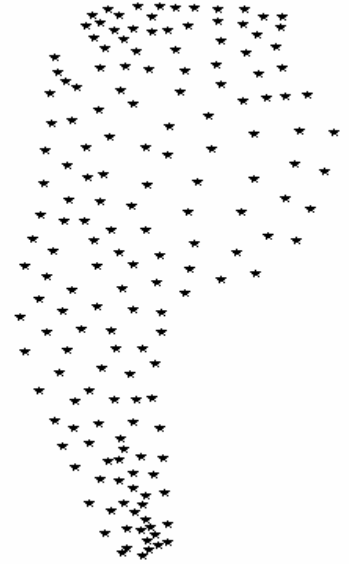

Fig. 3. Geographical data

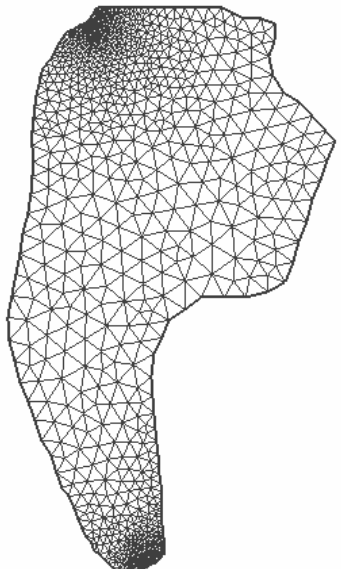

Fig. 4. Unstructured net with triangular elements

On the gate out there are the conditions of concentration: $\partial C_{i} / \partial n=0(\mathrm{i}=1 \ldots \mathrm{m})$ where $\mathrm{n}$ is the out orthogonal vector onto the gate out of lake.

The measurement positions are described in the following figure

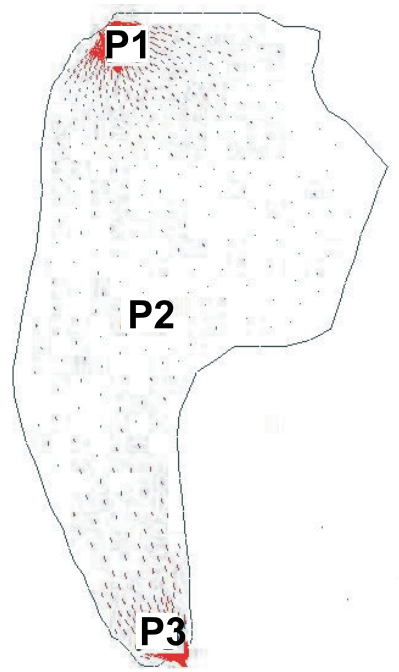

Fig. 5. The measurement positions on the lake

With the previous algorithm, the concentration results of $\mathrm{BOD}_{5}, \mathrm{SO}_{4}, \mathrm{COD}$ are obtained and described in the Figures 6-9 

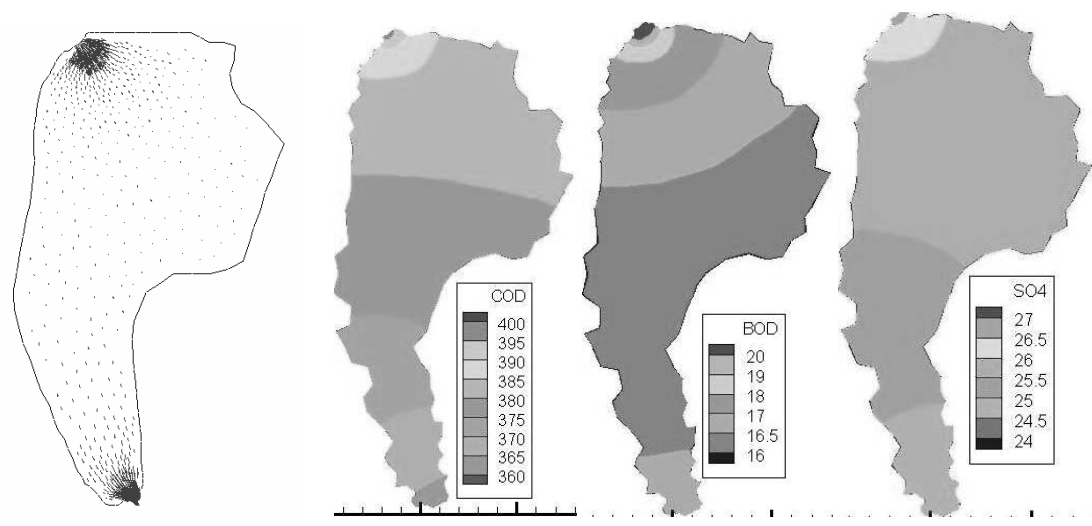

Fig. 6. Velocity and substance concentration fields $\mathrm{COD}, \mathrm{BOD}_{5}$, and $\mathrm{SO} 4$

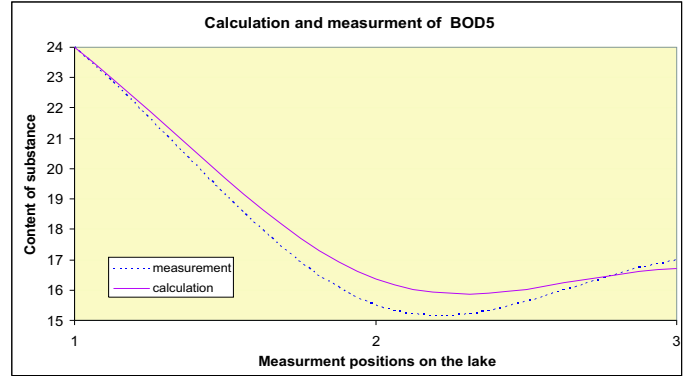

Fig. 7. Calculation and measurement of $\mathrm{BOD}_{5}$ contents at some points on the lake

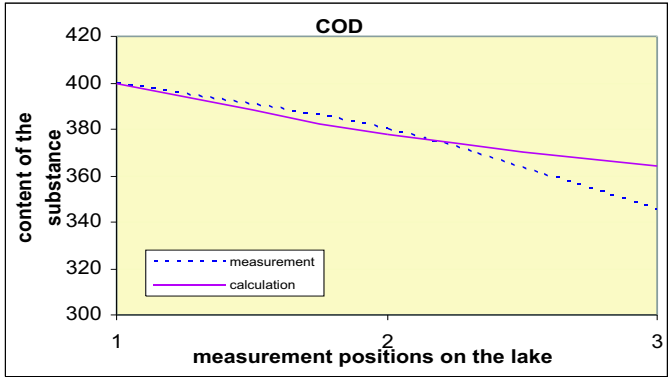

Fig. 8. Calculation and measurement of COD contents at some points on the lake

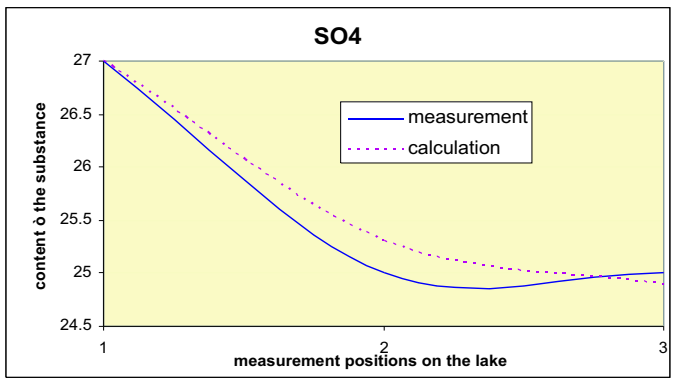

Fig. 9. Calculation and measurement of $\mathrm{SO}_{4}$ contents at some points on the lake

\section{CONCLUSION}

From the calculation results described by the transmission pictures of $\mathrm{BOD}_{5}, \mathrm{COD}$ $\mathrm{SO}_{4}$, it is easily to see that the calculation contents of these substances are closed to the measurements. In the middle of lake there are some errors between measurements and simulations of $\mathrm{BOD}_{5}, \mathrm{COD}$, and $\mathrm{SO}_{4}$. These errors can be explained that the contents of 
pollution substances are also depending on lake's temperatures, alga activates, and sunshine... These influences aren't considered in simulation process. The model can be used to simulate the transmission of substance combination in water with unlimited number of them if we have enough data. For the values of coefficients $\mathrm{k}_{i, j}(i, j=1, \ldots, m)$ in combination pollution sources $\mathrm{f}_{i}(i=1, . ., m)$ from the right side of equation $(7)$ we need to get the experimental results from the Institute of Chemistry.

With the results of simulation, the model can be developed and considered as a supported tool to calculate substance contents and study water quality for the pollution problems in our country.

\section{ACKNOWLEDGEMENT}

The authors express deep gratitude to Assoc. Prof. Hoang Van Lai, Dr. Trinh Anh Duc for their helps in the process realizing this paper. Simultaneously, they are grateful to the VAST's pollution project and basic foundation (NAFOSTED) for their supports for this research.

\section{REFERENCES}

[1] Doan Xuan Thuy, Hoang Van Lai, Dinh Van Manh, Tran Thu Ha, Nguyen Phu Duc, Le Duy Hung, Experiment simulation of pollutant transfers on reservoir, Scientific collection, National conference of Fluid and Gas Mechanic Meeting (2007) 555-564.

[2] P.A. Sleigh, P.H. Gaskell, M. Berzins and N.G. Wright, An unstructured Finite Volume Algorithm for predicting Flow in Rivers and Estuaries, Computers \& Fluids 27 (1998) 479-508.

[3] Nguyen Tat Dac, Mathematical model for flows and water quality in river system, Argiculture publish house (2004).

[4] Duong Ngoc Hai, Some basic problems of calculating air and water pollution, Hanoi National University Publish house (2006).

[5] C.Licht, Tran Thu Ha, Quoc phong Vu, On some linearized problems of shallow water flows, Differential and Integral equations 22 No 3-4 (2009) 275-283.

Received May 25, 2010

\section{MÔ HİNH LAN TRUYỀN Ô NHIÊิM NƯỚC HAI CHIỀU VÀ TÍNH MÔ PHỎNG CHO MỘT HỒ CHỨA TỰ NHIÊN}

Ngày nay, vấn đề ô nhiễm nước trong hồ chứa trở nên rất cấp thiết. Việc mô tả quá trình lan truyền chất trong hồ chứa đóng vai trò rất quan trọng trong việc nâng cao chất lượng cuộc sống của nhân dân. Trong bài báo này mô hình toán hai chiều mô tả quá trình lan truyền chất trong một hồ chứa ở Hà Nội được nghiên cứu. Phương pháp phần tử khối được sử dụng. Các ảnh hưởng tương tác của các chất trong hồ được nghiên cứu và các kết quả tính toán được so sánh với thực đo. 